Jurnal Tarbawi| Volume 2|No 1| ISSN 2527-4082| 33

\title{
PERANAN GURU PENDIDIKAN AGAMA ISLAM DALAM MEMBIASAKAN SISWA SHALAT BERJAMA'AH
}

\author{
Sitti Satriani Is ${ }^{1}$ \\ ${ }^{* 1}$ Pendidikan Agama Islam Fakultas Agama Islam| Unismuh Makassar
}

\begin{abstract}
ABSTRAK
Jenis penelitian ini bersifat deskriptif analitik, yakni suatu jenis penelitian yang sifatnya mengungkap dan menggambarkan fakta-fakta atau yang di peroleh secara mendalam dan apa adanya. lokasi dan objek penelitian bertempat di SMP Negeri 20 Bulukumba. Adapun jumlah populasi 366 orang siswa dan sampel 100 orang. Adapun Peran guru pendidikan agama Islam dalam membiasakan siswa Shalat berjamaah yaitu Peranan Guru Agama Islam Melalui Keteladanan Hasil angket menunjukkan bahwa 65 (65\%) berpendapat bahwa guru sangat berperan dalam memberikan keteladanan, 26 (26\%) menunjukkan berperan, 9 (9\%) menunjukkan kurang berperan dan 0 (0\%), Peran Guru Pendidikan Agama Islam Melalui Pembiasaan, hasil angketnya 59 (59\%) mengatakan sangat berperan, 33 (33\%) mengatakan berperan, 8 (8\%) orang mengatakan kurang berperan dan 0(0\%) yang mengatakan tidak berperan Peranan Guru Pendidikan Agama Islam Melalui pemberian Nasehat hasil anggket tersebut diatas menunjukkan bahwa upaya guru memberikan nasehat ketika lalai dalam melaksanakan shalat berjamaah siswa, sangat sering 58 (58\%), sering 23 (23\%) kadang-kadang 19 (19\%) dan tidak pernah 0 (0\%) dan Peranan Guru Pendidikan Agama Islam dalam metode Perhatian/ Pengawasan. hasilnya menunjukkan 64 (64\%) sangat sering, 22 (22\%) sering, kadang-kadang 14 (14\%) kadang-kadang dan 0 (0\%) tidak pernah.
\end{abstract}

\section{Kata Kunci : Guru pendidikan agama islam, Siswa, Shalat berjamaah}

\begin{abstract}
This type of research is descriptive analytic, the type of research are nature reveal and describe the facts or obtained in depth and what it is. Location and object of research located at SMP Negeri 20 Bulukumba. The total population of 366 students and a sample of 100 people. The role of Islamic education teacher in familiarizing students pray congregation of Islamic Religious Teacher Role Through Exemplary Results of questionnaire showed that 65 (65\%) argue that teachers play a role in giving exemplary, 26 (26\%) showed role, $9(9 \%)$ showed (33\%) said that the role, $8(8 \%)$ people say less play and $0(0 \%)$, the role of Islamic Education Teacher Through Habituation, ) Who said not to play the role of Islamic Religious Education Teachers Through the giving of the above results, the teacher's suggestion of giving advice when neglecting in performing the congregational prayers is very often $58(58 \%)$, often $23(23 \%)$ sometimes $19(19 \%)$ and never $0(0 \%)$ and the role of Islamic Education Teachers in the Attention / Control method. The results show $64(64 \%)$ very often, 22 (22\%) often, sometimes 14 (14\%) occasionally and $0(0 \%)$ never.
\end{abstract}

Keywords: Islamic religious teachers of education, students, pray congregation 


\section{PENDAHULUAN}

Pendidikan agama Islam mempunyai peranan penting dalam pembangunan suatu bangsa, karena keberhasilan suatu bangsa ditentukan oleh faktor manusianya, dalam hal ini pendidikan pada dasarnya merupakan suatu proses perubahan perilaku, melalui usaha perubahan sikap, watak, serta melatih diri dalam keterampilan yang bermanfaat. Di dalam masyarakat, dari yang paling terbelakang sampai yang paling maju, guru memegang peranan penting, hampir tanpa kecuali, ada masyarakat yang mengakui pentingnya peranan guru itu dengan cara yang lebih kongkrit dari pada masyarakat yang lain. Namun demikian, masih ada masyarakat yang menyangsingkan besarnya tanggung jawab guru. Banyak orang tua yang kadangkadang merasa cemas akan kemampuan guru sewaktu menyaksikan anak-anak mereka berangkat ke sekolah. Eva L. Bakir (2001:1)

Guru adalah unsur manusiawi dalam pendidikan. Guru adalah figur manusia sumber yang menempati posisi dan memegang peranan penting dalam pendidikan. Ketika semua orang mempersoalkan masalah dunia pendididkan, figur guru mesti terlibat dalam agenda pembicaraan, terutama yang menyangkut persoalan pendidikan formal di sekolah. Hal itu tidak dapat disangkal, karena lembaga pendidikan formal adalah dunia kehidupan guru, sebagian besar waktu guru ada di sekolah, sisanya ada di rumah dan masyarakat.

Di sekolah guru hadir untuk mengabdikan diri pada umat manusia dalam hal ini anak didik. Negara menuntut generasi yang memerlukan pembinaan dan bimbingan dari guru. Guru dengan sejumlah buku yang terselip di pinggang datang ke sekolah diwaktu pagi hingga petang sampai waktu mengajar dia hadir di sekolah untuk bersama-sama berlajar dengan sejumlah anak didik yang sudah menantinya untuk diberikan pelajaran. Anak didik ketika itu haus akan ilmu pengetahuan dan siap untuk menerimanya dari guru. Ketika itu guru sangat berarti sekali bagi anak didik. Kehadiran seorang guru di kelas merupakan kebahagiaan bagi mereka apalagi bila pigur guru itu disenangi oleh mereka. Syaiful Bahri Djamarah (2001:1)

Keberhasilan pendidikan manusia ditentukan oleh pemahamannya akan sumber pendidikan terhadap proses belajar mengajar, sebagaimana dirasakan oleh manusia secara keseluruhan, terlebih-lebih anak didik 
(siswa) pada khususnya, utamanya masalah pendidikan agama Islam. Dengan meningkatnya madrasahmadrasah dan sekolah-sekolah sekarang ini didirikan, maka perlu lebih ditegaskan bahwa kebutuhan manusa terhadap pendidikan, bukan hanya sekedar untuk mengembangkan aspekaspek individualisasi dan sosialisasi, melainkan juga merupakan suatu hal yang dapat mengarahkan perkembangan manusia dalam beriptek dan berimtak, khususnya di SMP Negeri 20 Bulukumba. Sebagaimana firman Allah dalam (QS. Al-Mujadilah (58):11).

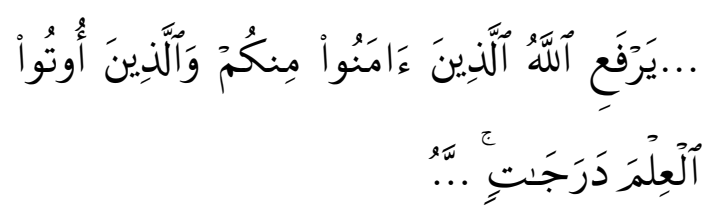

Terjemahnya:

... "Niscaya Allah akan meninggikan orang-orang yang beriman di antaramu dan orang-orang yang deberi ilmu pengetahuan beberapa derajat"... (Departemen Agama RI, Al-Qur'an dan Terjemahnya, $1996: 911$ )

Seorang pendidik yang bijaksana sudah barang tentu terus mengupayakan yang lebih efektif dan efisien dengan menerapkan dasar-dasar pendidikan yang berpengaruh terhadap anak secara mental dan moral, spritual, saintikal dan etos sosial anak, sehingga anak dapat mencapai kematangan yang sempurna, memiliki wawasan yang luas dan berkepribadian integral.
Mendidik anak menjadi manusia yang taat beragama Islam ini, pada hakikatnya adalah sangat sulit, apalagi hidup di era sekarang ini, era dimana anak-anak sampai orang tua cenderung untuk meniru budaya yang tidak lagi Islami. Maraknya tempattempat ibadah dalam hal ini Masjid yang dibangun begitu megahnya, mulai dari pelosok kota hingga pelosok desa yang sangat terpencil sebagai wujud kesadaran bahwa mereka sadar akan dirinya umat Islam. Namun kebanyakan dari jama'ah Masjid adalah kalangan orang yang sudah berkeluarga atau orang yang berusia lanjut. Dewasa ini lembaga pendidikan (sekolah) baik negeri maupun swasta, pemerintah mengupayakan untuk mendirikan tempat ibadah (Masjid) di lingkungan lembaga tersebut, dalam hal ini untuk mengupayakan agar setiap generasinya khususnya generasi Islam yang sadar akan dirinya sebagai ummat Islam. Berdasarkan dari latar bekalang diatas, penulis dapat merumuskan permasalahan sebagai berikut :

1. Bagaimana peranan guru pendidikan agama Islam dalam membiasakan siswa shalat berjama'ah di SMP Negeri 20 Bulukumba?

2. Faktor pendukung dan hambatanhambatan apa saja yang dihadapi guru pendidikan agama Islam dalam membiasakan siswa shalat berjama'ah di SMP Negeri 20 Bulukumba? 


\section{METODE PENELITIAN}

Jenis penelitian ini bersifat deskriptif analitik, yakni suatu jenis penelitian yang sifatnya mengungkap dan menggambarkan fakta-fakta atau yang di peroleh secara mendalam dan apa adanya.

Tabel. 1 Populasi

\begin{tabular}{|c|c|c|c|c|}
\hline \multirow{2}{*}{ No } & \multirow{2}{*}{$\begin{array}{c}\text { Tingkatan } \\
\text { Kelas }\end{array}$} & \multicolumn{2}{|c|}{$\begin{array}{c}\text { Jumlah } \\
\text { siswa }\end{array}$} & \multirow{2}{*}{ Jumlah } \\
\cline { 3 - 4 } & & LK & PR & \\
\hline 1. & KELAS I & 60 & 77 & 137 \\
\hline 2. & KELAS II & 47 & 73 & 120 \\
\hline 3. & $\begin{array}{c}\text { KELAS } \\
\text { III }\end{array}$ & 51 & 58 & 109 \\
\hline \multicolumn{2}{|c|}{ JUMLAH } & 158 & 208 & 366 \\
\hline
\end{tabular}

Tabel. 2 Sampel

\begin{tabular}{|c|c|c|c|c|}
\hline \multirow[t]{2}{*}{ No } & \multirow[t]{2}{*}{$\begin{array}{c}\text { Tingkatan } \\
\text { Kelas }\end{array}$} & \multicolumn{2}{|c|}{$\begin{array}{c}\text { Jumlah } \\
\text { siswa }\end{array}$} & \multirow[t]{2}{*}{ Jumlah } \\
\hline & & LK & PR & \\
\hline 1. & I. 1 & 15 & 15 & 30 \\
\hline 2. & II. 2 & 15 & 15 & 30 \\
\hline 3. & III.1 & 20 & 20 & 40 \\
\hline \multicolumn{2}{|c|}{ JUMLAH } & 50 & 50 & 100 \\
\hline
\end{tabular}

Untuk mendapatkan data yang relevan dengan masalah yang diteliti, agar hipotesis dapat diuji maka yang dianggap dapat atau tepat digunakan adalah angket, wawancara, dokumentasi dan observasi. Metode pengumpulan data serta keterangan, yang diperlukan dalam penyusunan tesis ini, dengan menggunakan beberapa metode yang lazim dipakai dalam suatu penelitian yaitu:

1. Library Research (penelitian kepustakaan)

2. Field Research (penelitian lapangan)

\section{HASIL PENELITIAN DAN PEMBAHASAN}

\section{Peranan Guru Pendidikan Agama Islam dalam Membiasakan Siswa Shalat berjamaa}

Dalam pelaksanaan program membiasakan siswa sholat berjamaah di SMP Negeri 20 Bulukumba banyak terdapat kegiatan didalamnya. Kegiatan itu terbagi dalam 2 kategori, yaitu :

1. Shalat berjamaah Materi yang ada adalah materi ibadah dimana siswa dibiasakan untuk shalat berjamaah tidak hanya di sekolah tetapi di luar lingkungan sekolah.

2. Guru juga menekankan keutamaan shalat berjamaah. Untuk tingkat SLTP materi ibadah adalah mementingkan amal perbuatannya (praktek) serta ditambah dengan menerangkan mana yang perlu dan mana yang sunah di antara amal perbuatan.

Begitu juga diterangkan sesuatu yang membatalkan serta hikmah-hikmahnya untuk 
kehidupan perseorangan dan kebahagiaan masyarakat. Selain itu juga diterangkan tujuan amal ibadah yaitu untuk mengingat Allah dan mohon hidayah dan taufik kepada-Nya, supaya kita selamat dan berbahagia di dunia dan akhirat. Sebab itu segala bacaan dalam shalat harus muridmurid mengetahui arti dan maksudnya, sehingga shalat itu dikerjakan dengan jasmani dan rohani, bukan gerak-gerik saja seperti shalat anak-anak. Metode yang digunakan dalam kegiatan ini yaitu:

1. Dengan pendahuluan misalnya guru menanyakan kepada murid bagaimana cara mengerjakan amal ibadah yang hendak diajarkannya.

2. Dengan bertanya jawab dengan siswa tentang bacaanbacaan dan perbuatan dalam amal ibadah itu satu demi satu.

3. Menyebutkan ayat Al-Quran atau Hadis yang berhubungan dengan amal perbuatan yang benar, Kegiatan ini merupakan praktek kegiatan intra kurikuler. Karena terbatasnya waktu maka kemungkinan siswa untuk menguasai materi sanagt terbatas.
Adapun Peran guru pendidikan agama Islam dalam membiasakan siswa Shalat berjamaah adalah :

\section{Peranan Guru Agama Islam Melalui Keteladanan}

Keteladanan dalam pendidikan merupakan metode yang paling berpengaruh dan terbukti paling berhasil dalam mempersiapkan dan membentuk aspek moral, spiritual, dan etos sosial anak didik. Mengingat pendidik adalah seorang figur terbaik dalam pandangan anak didik, yang kepribadian dan sopan santunnya, disadari atau tidak akan ditiru oleh anak didik. Bahkan bentuk perkataan, perbuatan dan kepribadian guru akan senantiasa tertanam dalam kepribadian anak didik sebagaimana nabi menjadi suri teladan bagi umatnya sebagaimana firman Allah dalam (QS.Al-Ahzab (34):21).

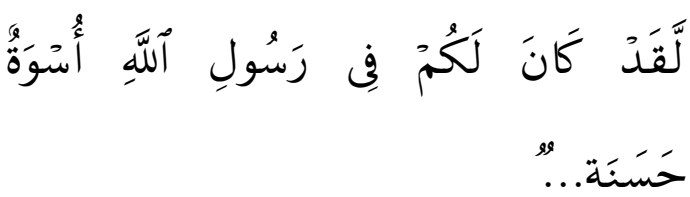

Terjemahnya:

"Sesungguhnya telah ada pada (diri) Rasulullah itu suri teladan yang baik bagimu"... ( Departemen Agama RI, AlQuran dan Terjemahannya, 1996:360)

Untuk mengetahui hasil penelitian tentang keteladanan yang di berikan guru pendidikan agama islam kepada siswa dalam shalat berjamaah dapat dilihat pada table berikut: 
Tabel III

Peranan Guru PAI

Melalui Metode Keteladanan

\begin{tabular}{|l|c|c|}
\hline $\begin{array}{l}\text { Kategori } \\
\text { Jawaban }\end{array}$ & Frekuensi & Presentase \\
\hline Sangat baik & 65 & $65 \%$ \\
\hline Baik & 26 & $6 \%$ \\
\hline Kurang baik & 9 & $9 \%$ \\
\hline Tidak baik & - & - \\
\hline Jumlah & 100 & $100 \%$ \\
\hline
\end{tabular}

Hasil angket menunjukkan bahwa 65 $(65 \%)$ berpendapat bahwa guru sangat berperan dalam memberikan keteladanan, 26 (26\%) menunjukkan berperan, $9(9 \%)$ menunjukkan kurang berperan dan $0(0 \%)$ menunjukkan tidak berperan, Seringnya guru mencontohkan kepada siswa tentang shalat berjamaah di mesjid menjadikan anak selalu atau rutin melaksanakan shalat berjamaah, selanjutnya jika hal tersebut kadangkadang di contohkan oleh guru maka siswa tersebut kadang-kadang pula melaksanakan shalat berjamaah, malah anak tidak akan pernah mendirikan shalat berjamaah jika guru sendiri tidak pernah melaksanakan shalat berjamaah.

\section{Peran Guru Pendidikan Agama Islam Melalui Pembiasaan}

Pembiasaan adalah upaya praktis dalam pendidikan dan pembinaan anak. Hasil dari pembiasaan yang dilakukan seorang pendidik adalah terciptanya suatu kebiasaan bagi anak didiknya. "Kebiasaan itu adalah suatu tingkah laku tertentu yang sifatnya otomatis, tanpa direncanakan dulu, serta berlaku begitu saja tanpa dipikir lagi" ( Edi Suardi, tt. : 123 ). Seorang anak yang terbiasa mengamalkan nilai-nilai ajaran Islam lebih dapat diharapkan dalam kehidupannya nanti akan menjadi seorang Muslim yang saleh.

\section{Tabel IV \\ Peranan Guru PAI}

dalam Metode Pembiasakan Siswa

Shalat Berjamaah

\begin{tabular}{|l|c|c|}
\hline $\begin{array}{c}\text { Kategori } \\
\text { Jawaban }\end{array}$ & $\begin{array}{c}\text { Frekuen } \\
\text { si }\end{array}$ & $\begin{array}{c}\text { Present } \\
\text { ase }\end{array}$ \\
\hline $\begin{array}{l}\text { Sangat } \\
\text { Berperan }\end{array}$ & 59 & $59 \%$ \\
\hline Berperan & 33 & $33 \%$ \\
\hline $\begin{array}{l}\text { Kurang } \\
\text { Berperan }\end{array}$ & 8 & $8 \%$ \\
\hline $\begin{array}{l}\text { Tidak } \\
\text { Berperan }\end{array}$ & - & - \\
\hline Jumlah & 100 & $100 \%$ \\
\hline
\end{tabular}

Berdasarkan jawaban angket item no.2 di atas ternyata menunjukkan bahwa 59 (59\%) mengatakan sangat berperan, 33 (33\%) mengatakan berperan, $8(8 \%)$ orang mengatakan kurang berperan dan $0(0 \%)$ yang mengatakan tidak berperan, melihat hal tersebut peranan guru pendidikan agama Islam dalam menerapkan metode pembiasaan melaksanakan Shalat berjamaah sangat besar peranannya, karena dengan pembiasaan tersebut secara otomatis ketika anak mendengar azan akan tergerak hatinya untuk melaksanakan sholat berjamaah. 


\section{Peranan Guru Pendidikan Agama Islam Melalui pemberian Nasehat.}

Metode pendidikan semacam ini cukup berhasil dalam pembentukan akidah siswa dan mempersiapkan baik secara moral, emosional, maupun sosial yang merupakan pendidikan anak dengan petuah memilki pengaruh yang cukup besar dalam membuka mata kesadaran anak-anak. dengan demikian, para pendidik hendaknya memahami betul akan hakikat ini dan menggunakan metode-metode Al-Qur'an dalam upaya memberikan nasehat, peringatan, dan bimbingan untuk mempersiapkan generasi muda yang tangguh, berwacana Islami dan pengetahuan yang handal.

\section{Tabel V}

Peranan Guru dalam Pemberian Nasehat Ketika Lalai dalam Melaksanakan Shalat Berjamaah

\begin{tabular}{|c|l|c|c|}
\hline No & $\begin{array}{l}\text { Kategori } \\
\text { Jawaban }\end{array}$ & Frekuensi & Persentase \\
\hline a. & Sangat & 58 & $58 \%$ \\
b. & Sering & 23 & $23 \%$ \\
c. & Sering & 19 & $19 \%$ \\
d & Kadang- & - & - \\
& kadang & & \\
& Tidak & & \\
& Pernah & & \\
\hline \multicolumn{2}{|l|}{ Jumlah } & 100 & $100 \%$ \\
\hline
\end{tabular}

Hasil anggket tersebut diatas menunjukkan bahwa upaya guru memberikan nasehat ketika lalai dalam melaksanakan shalat berjamaah siswa, sangat sering 58 (58\%), sering 23 (23\%) kadang-kadang 19 (19\%) dan tidak pernah $0(0 \%)$

\section{Peranan Guru Pendidikan Agama Islam dalam metode Perhatian/ Pengawasan.}

Pendidikan dengan memberi Perhatian/Pengawasan. Adapun yang dimaksud dengan perhatian adalah senantiasa mencurahkan perhatian penuh dan mengikuti perkembangan aspek aqidah dan moral anak, mengawasi dan memperhatikan kesiapn mental dan sosial, disamping selalu bertanya tentang situasi pendidikan jasmani dan kemampuan ilmiahnya. Islam, dengan keuniversaliannya prinsipnya dan peraturannya yang abadi, memerintah para bapak, ibu, dan pendidik untuk memperhatikan dan senantiasa mengikuti serta mengawasi anakanaknya dalam segala segi kehidupan dan pendidikan yang universal. Sebagaimana dalam surat At-Tahrim : 6, menguraikan suatu keharusan pengawasan ruang lingkup keluarga. Ali r.a mengartikan qu anfusakum dengan "didiklah dan ajarilah" sedangkan umar r.a menafsirkan "melarang mereka dari apa yang dilarang Allah". Untuk mengetahui dalam bentuk angket peranan guru pendidikan agama islam melalui pemberian perhatian dan nasehat di SMP 20 Bulukumba sebagai berikut : 
Tabel V

Peranan Guru dalam

Pemberian Perhatian/Pengawasan dalam Melaksanakan Shalat

Berjamaah

\begin{tabular}{|c|l|c|c|}
\hline No & $\begin{array}{l}\text { Kategori } \\
\text { Jawaban }\end{array}$ & Frekuensi & Persentase \\
\hline a. & Sangat & 64 & $64 \%$ \\
b. & Sering & 22 & $22 \%$ \\
c. & Sering & 14 & $14 \%$ \\
d & Kadang- & - & - \\
& kadang & & \\
& Tidak & & \\
& Pernah & & $100 \%$ \\
\hline \multicolumn{2}{|c|}{ Jumlah } & 100 & \\
\hline
\end{tabular}

Sering mengawasi atau memberikan pengawasan dalam melaksanakan shalat berjamaah hal ini dapat dilihat dari hasil angket menunjukkan 64 (64\%) sangat sering, $22(22 \%)$ sering, kadang-kadang 14 (14\%) kadang-kadang dan $0(0 \%)$ tidak pernah. Pemberian pengawasan tersebut merupakan bentuk perhatian terhadap siswa, dan pemberian perhatian dan pengawasan ini sangat efektif di laksanakan di SMP 20 Bulukumba.

Faktor Pendukung dan Penghambat dalam Membiasakan Siswa Shalat berjamaah.

Pendukung dan penghambat merupakan proses yang sering dihadapi oleh setiap orang dalam melakukan berbagai hal, sehingga dari ini diperlukan usaha yang sungguh-sungguh untuk banyak belajar memahami dan memunculkan sikap yang bijaksana dalam memenuhi faktor-faktor tersebut di atas.

Pendukung dan penghabat disiplin siswa dalam melaksanakan shalat berjamaah ketika berada dirumah Berdasarkan hasil wawancara penulis tersebut di atas dapat disimpulkan bahwa faktor pendukung dan penghambat yang dihadapi dalam membiasakan siswa shalat berjamaah adalah:

a. Faktor pendukung yaitu tersedianya sarana seperti toilet, tempat pengambilan air wudhu dan tempat ibadah dalam hal ini Mesjid sekolah.

b. Faktor penghambat secara internal masih adanya sebagian siswa kurang sadar akan pentingnya shalat berjamaah jama'ah, kurangnya bukubuku agama khususnya mengenai shalat berjamaah, sedangkan faktor eksternal adalah masih adanya sebagian orang tua yang kurang memberikan perhatian terhadap anaknya terhadap pentingnya shalat berjamaah

\section{KESIMPULAN}

Berdasarkan pembahasan pada bab-bab terdahulu, maka penulis dapat menyimpulkan sebagai berikut:

1. Peranan guru pendidikan agama Islam dalam membiasakan siswa shalat berjamaah adalah dengan melalui pendekatan keteladanan, 
praktek pembiasaan di mesjid sekolah serta nasehat-nasehat agar senantiasa siswanya tetap melaksanakan shalat berjamaah dimanapun mereka berada. Melalui peranan guru pendidikan agama Islam dalam membiasakan siswa shalat berjamaah maka hal itu berpengaruh terhadap pembentukan pribadi siswa selaku khalifah Allah di muka bumi.

2. Faktor pendukung dan penghambat dalam membiasakan siswa shalat berjamaah berjama'ah adalah tersedianya sarana berupa toilet, tempat pengambilan air wudhu dan mesjid di sekitar sekolah. Faktor penghambatnya secara interen adalah masih adanya sebagian siswa kurang sadar akan pentingnya shalat berjamaah (jama'ah), kurangnya buku-buku agama khususnya mengenai shalat berjamaah, sedangkan faktor eksternalnya adalah masih adanya sebagian orang tua kurang memberikan perhatian kepada anaknya terhadap pentingnya shalat berjamaah.

\section{DAFTAR PUSTAKA}

Ahmadi Abu, Metodik Khusus Pendidikan Agama (MKPA), Bandung: CV. Armico, 1986.

Al-Arasyi Athiyah Mohd, Dasar-Dasar Pendidikan Islam, (Cet. VI; Jakarta: Bulan Bintang, 1992).
Al-Hamd Ibrahim bin Muhammad, Bersama Pendidik Islam, Jakarta: Darul Haq, 2002.

Ali Muhammad, Guru Dalam Proses Belajar Mengajar, Cet. XI; Bandung: Sinar Baru, Algensindo, 2002

Al-Ja'fi Bukhari al-Imam, Shahih Bukhari, Juz. I, Cet. I; Bairut Libanon: Dar al-Kalam, 1987M/1407H.

Al-Azdi al-Sijastani al-Asy'at, Sunan Abi Daud, Cet. I; t.tp, 1969M/1388H.

Arikunto Suharsimi, Prosedur

Penelitian Suatu Pendekatan

Praktek, Cet. XII; Jakarta: PT.

Rineka Cipta, 2002.

Azhari Akyas, Psikologi Pendidikan, (Cet. I; Semarang: Dina Utama,1996).

Daradjat Zakiah, Ilmu Pendidikan Islam, (Cet. II; Jakarta: Bumi Aksara, 1992).

Departemen Agama RI, Al-Qur'an dan Terjemahnya, Semarang: PT. Karya Toha Putra, 1996

Departemen Pendidikan dan Kebudayaan, Kamus Besar Bahasa Indonesia, Cet. X; Jakarta: Balai Pustaka, 1999.

Djamarah Bahri Syaiful, Guru dan Anak Didik Dalam Interaksi Edukatif, Cet. I; Jakarta: PT. Rineka Cipta, 2000.

Ihsan Hamdani, Ihsan Fuad, Filsafat Pendidikan Islam, Cet. II; 
Bandung: CV. Pustaka Setia, 2001.

Lari Musawi Mujtaba Sayyid, Meraih Kesempurnaan Spritual, Bandung: Pustaka Hidayah.

Popham James W, Baker Eva L, Teknik Belajar Mengajar Secara Sistematis, Cet. II; Jakarta: PT. Rineka Cipta, 2001.

Ramayulis, Ilmu Pendidikan Islam, Cet. III; Jakarta: Kalam Mulia, 2002.

Sardiman, Interaksi dan Motivasi Belajar Mengajar Bagi Guru dan Calon Guru, Cet. VI; Jakarta:PT. Ikrar Mandiriabadi, 1996.

Shihab Quraish, M. Membumikan AlQur'an, Cet. XVIII; Bandung: Mizan, 1998.

Slameto, Belajar dan Faktor-Faktor yang Mempengaruhinya, Cet. III; Jakarta: PT. Rineka Cipta, 1995

Sriyono, Teknik Belajar Mengajar Dalam CBSA, Cet. I; Jakarta: PT. Rineka Cipta, 1992.

Surabaya IKIP Kurikulum Metodik

Didaktik Team, Pengantar Didaktik Metodik Kurikulum PBM, Cet. IV; Jakarta: CV. Rajawali, 1989.

Ulwan Nashih, Pendidikan Anak Dalam Islam, Cet. II; Jakarta: Pustaka Amani, 1999.

Zuhairini, Ghofir Abdul, Yusuf Slamet As, Metodik Khusus Pendidikan Agama Dilengkapi
Dengan system Modul dan Permainan Simulasi, Surabaya: Usaha Nasional, 1981. 